\title{
Międzynarodowe planowanie podatkowe z wykorzystaniem spółki prawa luksemburskiego
}

Tomasz Nowak*

\section{Wstęp}

Różnice między systemami podatkowymi poszczególnych państw są tak duże, że umożliwiają przedsiębiorstwom tworzenie rozmaitych struktur służących minimalizowaniu obciążeń podatkowych. Dostosowując działalność do obowiązujących przepisów podatkowych, przedsiębiorstwa mogą bezpośrednio wpływać na wysokość swoich zysków. Taka działalność przedsiębiorstw, nazywana międzynarodowym planowaniem podatkowym, jest efektywną metodą zmniejszania wymiaru opodatkowania, nawet do zera.

Obowiązujące w Polsce przepisy podatkowe nie określają prawnie dopuszczalnych granic planowania podatkowego. Nie nakazują ani nie zakazują one konkretnych zachowań, tylko wskazują na konsekwencje działań podatnika na gruncie tego prawa. Prawo podatkowe - które w odróżnieniu od np. prawa karnego nie zawiera nakazów lub zakazów określonych działań - ma charakter wynikowy, co oznacza, że wskazuje jedynie okoliczności faktyczne, których wystąpienie może pociągać za sobą obowiązek podatkowy. Podejmowanie przez podatników czynności mających na celu ograniczenie ciężaru podatkowego - pod warunkiem, że są one zgodne z przepisami prawa - nie stanowi obejścia przepisów prawa podatkowego i nie musi być przez podatników ukrywane. Planowanie podatkowe jest więc wyborem takiej metody osiągnięcia założonego celu ekonomicznego, która zapewni jak najniższe obciążenie podatkowe (Ladziński 2008).

Celem niniejszego opracowania jest przedstawienie istoty planowania podatkowego jako działania prawnie neutralnego, a także ocenienie możliwości

\footnotetext{
* Tomasz Nowak - magister, Uniwersytet Ekonomiczny w Poznaniu, Instytut Gospodarki Międzynarodowej, Katedra Finansów Międzynarodowych, tomasz.nowak@ue.poznan.pl
} 
wykorzystania funduszu inwestycyjnego zamkniętego (FIZ) oraz spółek prawa luksemburskiego - SCSp (Societe en Commandite Speciale) w międzynarodowym planowaniu podatkowym z uwzględnieniem obowiązujących przepisów prawa.

\section{Reakcje podatników na opodatkowanie}

Z punktu widzenia władzy publicznej opodatkowanie przedsiębiorstw podporządkowane jest podstawowej funkcji podatków - fiskalnej. Z perspektywy przedsiębiorstw funkcja ta znajduje swoje odzwierciedlenie w funkcji regulacyjnej, gdyż, jak twierdzi T. Famulska, ,podatki regulują (in minus) poziom zasobów pieniężnych przedsiębiorstw, przy czym jest to regulacja: jednostronna, przymusowa, bezzwrotna i nieodpłatna" (Famulska 2015). Zatem istota podatków oraz ich dwoisty charakter prowadzą do sprzeczności interesów władzy publicznej i przedsiębiorstw. Osiągnięcie oczekiwanego efektu fiskalnego zależy więc przede wszystkim od reakcji przedsiębiorstwa na to obciążenie.

Każde państwo ma własny system podatkowy uwzględniający poziom rozwoju państwa, specyfikę tradycji oraz uwarunkowania społeczno-ekonomiczne (Pach 2016). System ten nie może być jednak oderwany od uwarunkowań zewnętrznych - powinien być spójny nie tylko z pozostałymi instrumentami fiskalnymi stosowanymi w danym kraju, lecz również z instrumentami wykorzystywanymi na terytorium innych państw. W dobie globalizacji niespójność systemów podatkowych różnych państw może bowiem sprzyjać takim zjawiskom jak przenoszenie firm do rajów podatkowych i uciekanie od opodatkowania.

Polski system podatkowy charakteryzuje się dużą liczbą obciążeń oraz skomplikowaną konstrukcją poszczególnych podatków. Wpływa to na jego efektywność i może blokować rozwój przedsiębiorczości (Związek Przedsiębiorców i Pracodawców 2019). Ponadto podatki jako przymusowe daniny zmniejszają majątek przedsiębiorstwa, a ich ewentualne nieuiszczenie prowadzi do przymusowej egzekucji przez organy administracji skarbowej. Wpływ opodatkowania na wynik finansowy przedsiębiorstwa jest więc wyraźny i jednoznaczny. Opodatkowanie dochodu przedsiębiorstwa i obciążenie go podatkami obrotowymi zmniejszają wypracowane przez nie zyski, których znaczna część musi zostać odprowadzona do budżetu państwa.

Przedsiębiorstwa radzą sobie z podatkami na kilka sposobów, które mają różne skutki zarówno dla władzy publicznej, jak i dla samych przedsiębiorstw. W literaturze wyodrębnia się sześć rodzajów reakcji podatników na obciążenia podatkowe (Gwiazdowski 2019):

- wywiązanie się z obowiązku podatkowego,

- przerzucenie podatku, 
- legalne unikanie podatku,

- nadrobienie podatku,

- nielegalne uchylanie się od podatku,

- wycofanie się z części działalności będącej przedmiotem opodatkowania.

Podstawowym typem reakcji podatnika na nałożony obowiązek podatkowy jest próba ucieczki przed nim. W literaturze pojęcie ucieczki przed opodatkowaniem nie jest jednoznacznie określone. Może być ono rozpatrywane z dwóch punktów widzenia - podatnika oraz państwa. Dla podatnika ucieczka przed podatkami jest równoznaczna $\mathrm{z}$ jego niechęcią do wypełnienia ciążących na nim obowiązków podatkowych. Z perspektywy państwa ucieczka od opodatkowania oznacza zmniejszenie dochodów przysługujących państwu lub jednostkom lokalnym i ma związek z podejmowaniem przez podatnika aktywnych działań (Głuchowski 2002). Ucieczka przed podatkami nie ma jednak na celu obniżenia wpływów budżetowych - jest ona raczej wynikiem podjętych przez podatnika czynności mających na celu obniżenie należności podatkowej. Można zatem uznać, że ucieczką przed podatkami są wszelkie działania podatnika zmierzające do uniknięcia zapłaty podatku lub zmniejszenia jego wysokości (Gaudemet 2000). Podatnicy, którzy mają do wyboru dostosowanie się do przepisów podatkowych i wywiązanie się z obowiązku podatkowego lub podjęcie próby uniknięcia opodatkowania lub uchylenia się od niego, są skłonni decydować się na to drugie rozwiązanie (Pietrewicz 1996).

Ucieczka przed opodatkowaniem może mieć różne formy, jednak niezależnie od przyjętych kryteriów można wyodrębnić jej dwa główne rodzaje: unikanie podatku oraz oszustwa podatkowe. W polskiej literaturze panuje pewne zamieszanie terminologiczne definiujące tego typu zachowania, ale najprościej rzecz ujmując, można stwierdzić, że unikanie opodatkowania to zgodne z prawem działania podejmowane w celu redukcji obciążeń podatkowych, zaś oszustwa podatkowe są działaniami nielegalnymi, sankcjonowanymi przez obowiązujące przepisy prawa (Kuźniacki 2017).

$\mathrm{Na}$ kwestię zróżnicowana reakcji na podatek zwraca uwagę również T. Famulska, która zauważa trzy podstawowe możliwości (Famulska 1998):

- zapłacenie należnego podatku,

- omijanie opodatkowania,

- stosowanie planowania podatkowego.

Zapłata należnego podatku przez przedsiębiorstwo, które nie podejmuje żadnych czynności mających na celu zmniejszenie ciężaru podatkowego, jest dla władzy publicznej najkorzystniejszą sytuacją, ponieważ oznacza, że podatnik dostosował się do nałożonych na niego obowiązków podatkowych. Nie należy jednak utożsamiać takiej postawy z całkowitą biernością wobec nałożonego podatku - przedsiębiorstwo, rozliczając zobowiązanie podatkowe, dokładnie weryfikuje wysokość należnej kwoty oraz uwzględnia ewentualne ulgi i zwolnienia. 
Procedura ta może być punktem wyjścia do omijania opodatkowania (przybierającego różne formy w zależności od przyjętego kryterium). W odniesieniu do kryterium wysokości należnego podatku można wyróżnić omijanie częściowe i całkowite. W przypadku kryterium definitywności można mówić o definitywnym lub czasowym zaprzestaniu uiszczania należności podatkowych, przy czym czasowe oznacza opóźnienia w regulowaniu zobowiązań podatkowych (Kuzińska 2018). Przyjmując kryterium prawne, można zauważyć, że omijanie podatków może być zgodne z przepisami prawa, lecz niezgodne z jego celem; określa się je wtedy jako unikanie opodatkowania. Może być ono również dokonywane z naruszeniem prawa i przyjmować postać uchylania się od opodatkowania, które sankcjonowane jest przepisami karnymi ${ }^{1}$.

Jednak zarówno w literaturze, jak i w orzecznictwie podział na unikanie opodatkowania i uchylanie się od niego jest nieostry (Kuźnicki 2017). Warto przy tym zaznaczyć, że każda forma omijania opodatkowania ma wiele negatywnych konsekwencji (Gomułowicz 2013), ponieważ zakłóca działanie mechanizmów finansów publicznych i prywatnych, a także może przyczynić się do zmniejszenia konkurencyjności tych firm, które płacą podatki.

Inną możliwością reagowania na obciążenia podatkowe przez przedsiębiorstwa jest wdrożenie strategii podatkowej w ramach planowania podatkowego. Oznacza to traktowanie podatków jako ograniczeń działalności, które przy użyciu odpowiedniej strategii można niwelować. Podatek jest więc uiszczany, jednak jego wysokość jest efektem podjęcia pewnych działań, tj. skorzystania z udogodnień i rozwiązań, które przewiduje prawo. Chodzi przede wszystkim o analizę możliwych rozwiązań podatkowych i ewentualnych korzyści płynących z dostosowania się do oczekiwań ustawodawcy.

Największą swobodę w stosowaniu strategii podatkowych zapewniają przepisy regulujące podatek dochodowy, a zakres zarządzania podatkami wynika z przepisów podatkowych i jest ściśle uwarunkowany formą opodatkowania (Walicka 2012). Z punktu widzenia przedsiębiorstwa opodatkowanie dochodu jest najbardziej czytelną konstrukcją, gdyż zmniejsza wypracowaną w danym okresie nadwyżkę przychodów nad kosztami ich uzyskania. Opodatkowanie dochodu zależy głównie od formy prawnej działalności. Osoby fizyczne prowadzące działalność gospodarczą oraz wspólnicy spółek osobowych ${ }^{2}$ płacą podatek dochodowy od osób fizycznych. Podmioty posiadające osobowość prawną - tj. fundacje, stowarzyszenia, a przede wszystkim spółki kapitałowe, czyli spółki z ograniczoną odpowiedzialnością, akcyjne, a od 2014 r. również spółki komandytowo-akcyjne

\footnotetext{
${ }^{1}$ Art. 54 oraz art. 56 ustawy z dnia 10 września 1999 r. - Kodeks karny skarbowy sankcjonują uchylanie się od opodatkowania oraz oszustwo podatkowe jako czyny zagrożone karą pozbawienia wolności do lat pięciu.

${ }^{2}$ Zgodnie z ustawą z dnia 15 września 2000 r. - Kodeks spółek handlowych do spółek osobowych zalicza się: spółkę jawną, spółkę partnerską, spółkę komandytową i spółkę komandytowo-akcyjną.
} 
- są zobowiązane do płacenia podatku dochodowego od osób prawnych. Podatki dochodowe są obciążeniem każdego rodzaju osiągniętego dochodu i powodują ograniczenie zarówno bieżących, jak i długoterminowych możliwości finansowych przedsiębiorstw. Zmniejszają one również bezpośrednie korzyści właścicieli, ograniczając zyski z zaangażowanego przez nich kapitału.

Wpływ podatku dochodowego na płynność pracy przedsiębiorstwa oraz istniejące możliwości prawne sprawiają, że przedsiębiorcy w ramach planowania podatkowego skupiają się przede wszystkim na szukaniu rozwiązań pozwalających na obniżenie podatku.

\section{Analiza pojęcia unikania opodatkowania oraz istota międzynarodowego planowania podatkowego}

Percepcja zjawiska zmniejszania opodatkowania, które najczęściej nazywane jest optymalizacją podatkową lub unikaniem opodatkowania, w znacznej mierze zależy od stopnia tolerowania przez ustawodawcę, sądy i organy podatkowe danego państwa podejmowanych przez podatników działań w tym zakresie. Stopień tej tolerancji będzie najniższy w krajach o wysokim poziomie opodatkowania, charakteryzujących się transparentnymi i efektywnie funkcjonującymi systemami podatkowymi. Wyższy stopień tolerancji będzie występował w państwach o niskiej realnej stopie opodatkowania, które oferują podatnikom rozwiązania prawne pozwalające na zmniejszenie opodatkowania (do takich państw należą między innymi Luksemburg, Cypr i Lichtenstein).

Podatnicy i doradcy podatkowi postrzegają obniżanie opodatkowania inaczej niż organy podatkowe. Ci pierwsi zazwyczaj traktują działania mające na celu zmniejszenie opodatkowania jako legalną i zgodną z prawem optymalizację podatkową. Organy skarbowe niechętnie uznają takie działania za zgodne z obowiązującym prawem i traktują je jako unikanie opodatkowania.

Unikanie opodatkowania jest $\mathrm{w}$ istocie bardzo zbliżone do optymalizacji podatkowej. W obu przypadkach podatnik podejmuje działania, dzięki którym w sposób zgodny z prawem osiąga korzyść podatkową w postaci obniżenia wysokości należnego podatku lub zredukowania go do zera. Podstawowa różnica między optymalizacją podatkową a unikaniem opodatkowania polega na tym, że chociaż obie czynności są zgodne z przepisami prawa, to ta druga narusza ich cel.

Unikanie opodatkowania bywa również utożsamiane z planowaniem podatkowym, jednak głębsza analiza tych pojęć wykazuje, że są one różne. Ich cechą wspólną jest to, że oba bywają nieakceptowane przez organy podatkowe, ale tylko unikanie opodatkowania jest sprzeczne z celem przepisów prawa obowiązujących w danym państwie. W przypadku planowania podatkowego nie może być 
mowy o takiej sprzeczności, gdyż wykorzystuje ono luki i niezgodności między przepisami kilku państw. Nie można więc wskazać przepisów konkretnego państwa, których cel zostałby naruszony wskutek międzynarodowego planowania podatkowego.

Pojęcie unikania opodatkowania związane jest z podejmowanymi przez podatników działaniami, które nie są sankcjonowane przez prawo karne i mają dwie kumulatywne cechy (Kuźniacki 2017):

- działania podatników pozostają zgodne z przepisami prawa podatkowego i są transparentne dla organów podatkowych, które na ich podstawie mogą ustalić zobowiązanie podatkowe;

- ich działania, poza uzyskaniem korzyści podatkowej, nie mają istotnego celu gospodarczego.

Cecha pierwsza, czyli transparentność i przekazywanie informacji organom podatkowym, wyklucza unikanie opodatkowania z zakresu oszustw podatkowych, a druga - unikanie opodatkowania z zakresu planowania podatkowego.

Warto dodać, że w ostatnich kilku latach w Polsce wprowadzono restrykcyjne regulacje podatkowe mające na celu zwalczanie unikania opodatkowania. Mowa tu między innymi o:

- przepisach o kontrolowanych spółkach zagranicznych (CFC), które weszły w życie w styczniu 2015 r.;

- ogólnej klauzuli skierowanej przeciwko unikaniu opodatkowania, obowiązującej od lipca 2016 r.;

- zmianie przepisów w zakresie opodatkowania funduszy zamkniętych w odniesieniu do dochodów pasywnych uzyskiwanych za pośrednictwem transparentnych podatkowo spółek osobowych (od 1 stycznia 2017 r.);

- raportowaniu schematów podatkowych(MDR) obowiązujących od 1 stycznia $2019 \mathrm{r}$.

Wpływ klauzuli ogólnej w sprawie unikania opodatkowania oraz zmiany przepisów w zakresie opodatkowania FIZ na możliwości międzynarodowego planowania podatkowego $\mathrm{z}$ wykorzystaniem funduszu inwestycyjnego zamkniętego oraz spółek prawa luksemburskiego zostanie omówiony w dalszej części opracowania.

Podatnicy prowadzący działalność gospodarczą przywiązują coraz większą wagę do obciążeń podatkowych oraz skutków ekonomicznych opodatkowania i tworzą kompleksowe plany, które umożliwiają minimalizowanie obciążeń podatkowych (Griffin 2013). W praktyce, jak wskazuje M. Poszwa, takie działanie może być różnie określane, m.in. jako controlling podatkowy, polityka podatkowa, zarządzanie przez podatki czy też planowanie podatkowe (Poszwa 2007). Międzynarodowe planowanie podatkowe to co do zasady proces mający na celu taki wybór struktury planowanego zdarzenia gospodarczego, który zminimalizuje związany z nim ciężar podatkowy (Spoz 2012). Może on wykorzystywać luki 
i sprzeczności w prawie poszczególnych państw, ale zawsze pozostaje w zgodzie z obowiązującymi przepisami prawa.

Istotę planowania podatkowego oddaje sformułowana w Wielkiej Brytanii w 1936 r. zasada westminsterska, zgodnie z którą „każdemu przysługuje uprawnienie do takiego zgodnego z prawem prowadzenia swoich spraw, by zapłacić jak najniższy podatek. Jeśli komuś uda się osiągnąć taki skutek, chociażby jego pomysłowość nie została doceniona przez organy podatkowe albo innych podatników, nie może być on zmuszony do płacenia podatku w wyższej wysokości" (Orzeczenie Brytyjskiej Izby Lordów 2004).

W Polsce Naczelny Sąd Administracyjny niejednokrotnie podkreślał, że istotą działalności gospodarczej jest maksymalizacja zysku, a nie maksymalizacja zobowiązań podatkowych ${ }^{3}$. Ponadto żaden przepis prawa podatkowego, orzecznictwo czy doktryna prawa nie zabraniają podatnikowi wyboru takiego rozwiązania zgodnego z prawem i rzeczywistością, które podczas podejmowania decyzji gospodarczych byłoby dla niego bardziej korzystne na gruncie prawa podatkowego (wyrok NSA II FSK 2327/12 2019).

W doktrynie przyjmuje się więc, że jeżeli obowiązujący porządek prawny daje podatnikowi możliwość wyboru kilku legalnych konstrukcji pozwalających na osiągnięcie określonego celu gospodarczego, z których każda skutkować będzie innym wymiarem podatkowym, to wybór najkorzystniejszego rozwiązania nie może być traktowany jako obejście prawa. Planowanie podatkowe może opierać się na doborze form obrotu gospodarczego, które umożliwią osiągnięcie pożądanego rezultatu gospodarczego bez konieczności wkraczania w zakres obowiązku podatkowego. Każdy podatnik ma prawo do prowadzenia swoich działań tak, by idące za nimi obciążenia podatkowe były jak najniższe.

Najkorzystniejszą sytuacją dla podmiotu prowadzącego działalność transgraniczną jest więc zorganizowanie jej w taki sposób, aby generowany z niej dochód nie podlegał opodatkowaniu ani w państwie rezydencji, ani w państwie źródła lub podlegał opodatkowaniu możliwie niską efektywną stawką podatkową. Optymalna podatkowo struktura działalności często może decydować o przewadze konkurencyjnej przedsiębiorstwa na rynku, dlatego planowanie podatkowe przestaje być czymś niespotykanym i staje się standardem (Wyciślok 2013). Niewykluczone, że opracowywanie przez przedsiębiorstwa odpowiednich strategii podatkowych stanie się niebawem koniecznością, gdyż specyfika rynku i konkurenci z branży, którzy uzyskają dzięki nim przewagę, będą wymuszać na pozostałych dostosowanie się i podjęcie podobnych kroków.

Zrozumienie wykorzystywanych w międzynarodowym planowaniu podatkowym konstrukcji wymaga podkreślenia tego, że polega ono na całkowicie

${ }^{3}$ Por. wyrok NSA z dnia 31 stycznia 2002 r., sygn. I/SA/GD 771/01 oraz wyrok NSA z dnia 29 maja 2002 r., sygn. III SA 2602/00. 
legalnym korzystaniu z dostępnych instrumentów prawnych i finansowych, mających na celu zredukowanie obciążeń podatkowych, co czyni je zjawiskiem prawnie neutralnym (Lipowski 2004). Wykorzystując bilateralne umowy o unikaniu podwójnego opodatkowania, porozumienia międzynarodowe, a także wszelkie różnice w przepisach podatkowych różnych państw można redukować opodatkowanie przedsiębiorstwa. W większości krajów prawo do zakładania spółek i prowadzenia działalności gospodarczej w innych krajach jest fundamentem wolności gospodarczej. W związku z tym podmioty prowadzące działalność gospodarczą wykorzystują wszelkie możliwości zgodne z przepisami dotyczącymi zakładania i prowadzenia spółek zagranicznych, wykorzystywania transferów kapitałowych i tworzenia różnego rodzaju struktur podatkowych umożliwiających obniżenie podatku (Ignaciuk 2014).

Kluczową rolę w planowaniu podatkowym odgrywa wiedza z zakresu przepisów podatkowych. Gdy planowanie ma na celu zredukowanie obciążeń podatkowych poprzez optymalizację, jeszcze bardziej na znaczeniu zyskuje znajomość związków między zdarzeniami gospodarczymi a przepisami podatkowymi (Kudert i Jamroży 2007).

\section{Międzynarodowe planowanie podatkowe z wykorzystaniem spółki prawa luksemburskiego}

Jedna z metod międzynarodowego planowania podatkowego, mająca na celu minimalizowanie wysokości podatku dochodowego od osób prawnych, polega na tworzeniu struktur holdingowych z wykorzystaniem FIZ oraz luksemburskich spółek SCSp. Początkowo struktura ta obejmowała kilka podmiotów powiązanych kapitałowo, w których podmiotem dominującym był FIZ. Spółki zależne od FIZ były powiązane wertykalnie, zaś kluczową rolę odgrywały w nim spółki transparentne podatkowo, tj. luksemburskie spółki SCSp o statusie zbliżonym do polskich spółek komandytowo-akcyjnych.

Aby mogła powstać tego typu struktura, należało w pierwszej kolejności zawiązać spółkę prawa luksemburskiego SCSp oraz utworzyć FIZ. Następnie do spółki prawa luksemburskiego, w ramach objęcia wyemitowanych przez nią akcji, musiały zostać wniesione aportem udziały polskiej spółki komandytowej prowadzącej rzeczywistą działalność gospodarczą. Następnie akcje te przenoszono do FIZ w ramach zapisu na certyfikaty inwestycyjne. W ten sposób FIZ stawał się udziałowcem w spółce luksemburskiej, zaś wspólnicy polskiej spółki komandytowej otrzymywali certyfikaty inwestycyjne, które w dowolnym momencie mogły zostać umorzone w celu realizacji i wypłaty zysku. 
Schemat 1. Przykładowa struktura holdingowa z udziałem spółki prawa luksemburskiego SCSp i kierunek przepływu środków pieniężnych

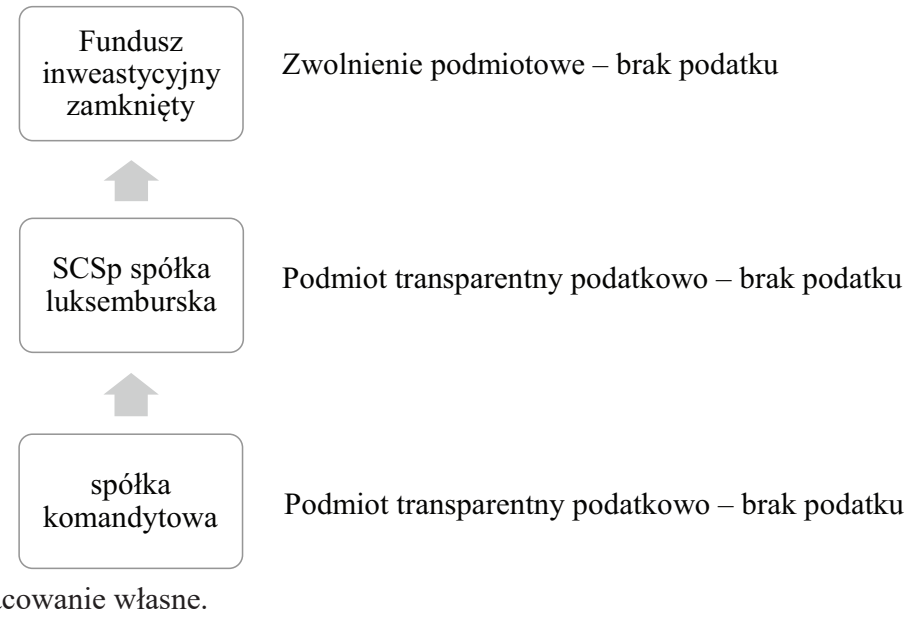

Na Schemacie 1 spółka komandytowa jest spółką operacyjną, która prowadzi rzeczywistą działalność gospodarczą generującą przychody. Wspólnikiem w spółce komandytowej, posiadającym dominujący udział w wypracowanym zysku, jest luksemburska spółka SCSp. Jest ona podmiotem transparentnym podatkowo ${ }^{4}$, więc wszelkie jej przychody i koszty są przypisywane udziałowcom, do których należy m.in. FIZ ${ }^{5}$. W takiej strukturze dochody spółki komandytowej z działalności operacyjnej powinny podlegać opodatkowaniu na poziomie udziałowca spółki luksemburskiej, czyli FIZ. Ten jednak do dnia 1 stycznia 2017 r., zgodnie z ustawą o podatku dochodowym od osób prawnych, mógł korzystać z przysługującego mu zwolnienia podmiotowego, a co za tym idzie - nie płacić podatku od wszelkich osiąganych dochodów. Obowiązek podatkowy może pojawić się dopiero po stronie uczestnika funduszu, który w celu realizacji zysku zażąda wykupu i umorzenia posiadanych certyfikatów inwestycyjnych ${ }^{6}$. Struktura ta pozwala nie tylko na odroczenie podatku dochodowego w czasie i jego zapłatę $\mathrm{w}$ dogodnym dla podatnika terminie, lecz również - i jest to jej najistotniejsza zaleta - na umorzenie certyfikatów inwestycyjnych w momencie, kiedy koszt ich

\footnotetext{
${ }^{4}$ SCSp jest spółką transparentną podatkowo dla wszystkich podatków, o których mowa w Konwencji między Rzeczypospolita Polską a Wielkim Księstwem Luksemburga w sprawie unikania podwójnego opodatkowania w zakresie podatków od dochodu i majątku.

${ }^{5} \mathrm{~W}$ omawianym schemacie, co do zasady, luksemburska spółka posiada również udziałowca w postaci luksemburskiej spółki S.A.R.L., która jest odpowiednikiem polskiej spółki z ograniczoną odpowiedzialnością. Jej udział w zysku spółki SCSp nie przekracza $0,1 \%$.

${ }^{6}$ Dochód z wykupu i umorzenia certyfikatów inwestycyjnych jest opodatkowany $19 \%$ podatkiem dochodowym od zysków kapitałowych. Dochód ten obliczany jest jako różnica pomiędzy przychodem z wykupu i umorzenia certyfikatów inwestycyjnych a kosztem ich nabycia.
} 
nabycia ${ }^{7}$ przewyższy przychód z jego umorzenia, powodując stratę podatkową i brak obowiązku zapłaty podatku dochodowego pomimo wypłacenia uczestnikowi środków pieniężnych.

Stan prawny umożliwiający planowanie podatkowe z wykorzystaniem FIZ oraz spółek prawa luksemburskiego utrzymywał się do końca 2016 r. - 1 stycznia 2017 r. zmienily się zasady opodatkowania FIZ podatkiem dochodowym od osób prawnych prowadzących inwestycję w spółki osobowe. Większość funduszy inwestycyjnych po zmianie ustawy o CIT nadal mogła korzystać ze zwolnienia podmiotowego od podatku dochodowego od osób prawnych. Ustawodawca przewidział, że nowe przepisy nie będą stosowane przez fundusze inwestycyjne otwarte (FIO) oraz specjalistyczne fundusze inwestycyjne otwarte (SFIO) utworzone na podstawie ustawy o funduszach inwestycyjnych, $\mathrm{z}$ wyłączeniem specjalistycznych funduszy otwartych stosujących zasady i ograniczenia inwestycyjne określone dla FIZ. Pozostałe fundusze, w szczególności FIZ, zostały zobowiązane do składania zeznań podatkowych, w których wykazywane są dochody z podziałem na dochody zwolnione przedmiotowo i opodatkowane, oraz opodatkowania dochodów z udziału w spółkach transparentnych stawką w wysokości 19\% CIT $^{8}$. FIZ, ustalając podstawę opodatkowania, sumuje wszystkie dochody w okresie rozliczeniowym ${ }^{9}$. Od tak ustalonej podstawy oblicza się wysokość zobowiązania podatkowego i ewentualnie zaliczki na zryczałtowany podatek dochodowy.

Począwszy od 1 stycznia 2017 r., FIZ, który posiada udział w spółce niebędącej podatnikiem podatku dochodowego, został zobowiązany do bieżącego rozliczania dochodów osiąganych z tytułu działalności gospodarczej prowadzonej przez tę spółkę. Także wtedy, gdy FIZ posiada udziały w spółce niebędącej podatnikiem podatku dochodowego (spółka $X$ ), która ma udział w innej spółce niebędącej podatnikiem podatku dochodowego (spółka Y), FIZ musi rozliczać na bieżąco zyski z działalności zarówno spółki X, jak i Y. Taka sytuacja zdarza się wtedy, gdy fundusz kontroluję spółkę prawa luksemburskiego SCSp, która kontroluje inną spółkę niebędącą podatnikiem podatku dochodowego, np. polską spółkę komandytową. Upraszczając, można stwierdzić, że po zmianie przepisów opodatkowane zostały dochody osiągane przez FIZ z tytułu udziału w zyskach

\footnotetext{
${ }^{7}$ Koszt nabycia certyfikatów inwestycyjnych zostaje ustalony w momencie aportu akcji luksemburskiej spółki SCSp do FIZ w ramach zapisów na emisję certyfikatów inwestycyjnych. W omawianym schemacie jest to transakcja bezgotówkowa.

${ }^{8}$ Opodatkowaniu podlegają wyłącznie dochody FIZ wskazane w art. 17 ust. 1 pkt 57 ustawy o CIT.

${ }^{9}$ Zgodnie z art. 17 ust. 1 pkt 57 lit. a ustawy o CIT opodatkowaniu podlegają na poziomie FIZ dochody (przychody) z udziału w spółkach niemających osobowości prawnej lub jednostkach organizacyjnych niemających osobowości prawnej, mających siedzibę lub zarząd na terytorium Rzeczypospolitej Polskiej lub w innym państwie, jeżeli zgodnie z przepisami podmioty te nie są traktowane jako osoby prawne i nie podlegają opodatkowaniu od całości swoich dochodów bez względu na miejsce ich osiągania.
} 
spółek, które nie są podatnikami podatku dochodowego. W obecnym stanie prawnym FIZ nie może inwestować w żaden polski podmiot niebędący podatnikiem podatku dochodowego ${ }^{10}$. Wyłączona została więc możliwość inwestowania w takie podmioty jak spółka cywilna, jawna, partnerska i komandytowa. Zgodne z prawem pozostały jednak inwestycje FIZ w akcje lub udziały zagranicznych spółek niebędących podatnikami podatku dochodowego, takich jak luksemburskie spółki SCSp ${ }^{11}$.

Przychody z udziału w spółce niebędącej podatnikiem podatku dochodowego są proporcjonalne do prawa wspólników do udziału w zysku. Na tej samej zasadzie ustala się udział każdego wspólnika w kosztach uzyskania przychodów oraz w wydatkach niebędących kosztami uzyskania przychodów.

Ustalenie dochodu na poziomie wspólników oznacza, że każdy z nich, stosując się do przepisów podatkowych, musi określić, czy powstał u niego przychód z określonego tytułu i czy poniesione w związku z tym koszty są kosztami uzyskania przychodów. Podatnicy CIT ustalają dochód z udziału w spółkach osobowych na podstawie ewidencji podatkowych (spółki osobowe są zobowiązane do ich prowadzenia).

Kwestię posiadanego przez wspólników udziału w spółce niemającej osobowości prawnej określa przede wszystkim statut lub umowa takiej spółki. W przypadku spółek SCSp udział FIZ w ich zysku wynosi zazwyczaj ok. 99,90\%. Z kolei udział SCSp w zyskach kontrolowanych przez siebie polskich spółek osobowych mieści się w przedziale 99,00-99,90\%. W praktyce FIZ jako podatnik CIT będzie rozliczał wyłącznie dochody uzyskiwane przez polskie spółki komandytowe na podstawie informacji otrzymywanych od tych podmiotów. Spółki te, zgodnie z ustawą o rachunkowości, prowadzą pełną księgowość i przekazują informacje na temat wyniku podatkowego swoim komplementariuszom będącym podatnikami podatku CIT.

Podstawową formą rozliczeń z tytułu podatku dochodowego od osób prawnych są zaliczki miesięczne. Ich wysokość oblicza się, mnożąc odpowiednią stawkę podatku przez dochód podlegający opodatkowaniu CIT osiągnięty przez FIZ od początku roku. Dochodem jest różnica między sumą przychodów a kosztami ich uzyskania. Załóżmy, że FIZ posiada akcje w spółce SCSp uprawniające do udziału w zysku tej spółki wynoszącego 99,90\%.

\footnotetext{
${ }^{10}$ Zob. art. 145 ustawy z dnia 27 maja 2004 r. o funduszach inwestycyjnych i zarządzaniu alternatywnymi funduszami inwestycyjnymi.

${ }^{11}$ Spółki niebędące osobą prawną są jednostkami organizacyjnymi, które osiągają dochody z tytułu prowadzonej działalności gospodarczej oraz które prowadzą ewidencję służącą za podstawę ustalania tego dochodu. W świetle art. 5 ust. 1 ustawy o CIT przyjmuje się jednak, że do celów podatkowych dochód z udziału w spółce niebędącej osobą prawną ustalany jest na poziomie jej wspólników. Każdy wspólnik spółki niebędącej osobą prawną ma obowiązek rozliczyć przychód (dochód) z udziału w tej spółce.
} 
Z kolei SCSp ma udział w polskiej spółce niebędącej osobą prawną w wysokości 99,90\%. Polska spółka osiągnęła w styczniu 2017 r. dochód w wysokości $50000 \mathrm{z}^{12}$.

Schemat 2. Przykładowa struktura własności z wykorzystaniem spółki SCSp

\begin{tabular}{|c|c|c|c|c|}
\hline FIZ & Udział $99,90 \%$ & SCSp & Udział $99,90 \%$ & Polska spółka komandytowa \\
\hline
\end{tabular}

Źródło: opracowanie własne.

W takiej sytuacji FIZ powinien uwzględnić wynik polskiej spółki komandytowej w wysokości 98,8001\% (procent z procentu: 99,90\% × 99,90\%) zgodnie z Tabelą 1 .

Tabela 1. Przykładowa symulacja opodatkowania dochodu przez FIZ w związku z udziałem w spółce prawa luksemburskiego SCSp po 1 stycznia $2017 \mathrm{r}$.

\begin{tabular}{|l|c|c|c|}
\cline { 2 - 4 } \multicolumn{1}{c|}{} & $\begin{array}{c}\text { Obliczenie } \\
\text { dochodu }\end{array}$ & $\begin{array}{c}\text { Podstawa } \\
\text { opodatkowania }\end{array}$ & $\begin{array}{c}\text { Podatnik } \\
\text { CIT }\end{array}$ \\
\hline $\begin{array}{l}\text { Przykładowy dochód podatkowy osiągany } \\
\text { przez polską spółkę komandytową }\end{array}$ & $50000 \mathrm{zł}$ & - & - \\
\hline $\begin{array}{l}\text { Udział komplementariusza polskiej spółki } \\
\text { komandytowej w wysokości 0,1\% udziału }\end{array}$ & $(50000 \times 0,1 \%)$ & $50 \mathrm{zł}$ & TAK \\
\hline $\begin{array}{l}\text { Udział spółki SCSp w wysokości 99,9\% udzia- } \\
\text { łu w zysku polskiej spółki komandytowej }\end{array}$ & $(50000 \times 99,9 \%)$ & $49950 \mathrm{zł}$ & NIE \\
\hline $\begin{array}{l}\text { Udział spółki S.A.R.L. w spółce SCSp w wyso- } \\
\text { kości 0,1\% }\end{array}$ & $(49950 \times 0,1 \%)$ & $50 \mathrm{zł}$ & TAK \\
\hline $\begin{array}{l}\text { Udział FIZ w spółce SCSp w wysokości } \\
99,90 \%\end{array}$ & $(49950 \times 99,9 \%)$ & $49990,05 \mathrm{zł}$ & TAK \\
\hline
\end{tabular}

Źródło: opracowanie własne na podstawie ustawy z dnia 15 lutego 1992 r. o podatku dochodowym od osób prawnych.

Zgodnie z powyższym przykładem $\mathrm{w}$ obecnym stanie prawnym fundusz jest zobowiązany do końca następnego okresu rozliczeniowego wpłacić zaliczkę na podatek CIT w kwocie 9498 zł, tj. 19\% kwoty 49991 zł, która stanowi jego dochód z tytułu udziału w spółce prawa luksemburskiego SCSp. FIZ od 1 stycznia 2017 r. utraciły podmiotowe zwolnienie z opodatkowania, zachowując zwolnienie przedmiotowe, jednak zyski ze spółek transparentnych podatkowo nie kwalifikują się do takiego zwolnienia. Prawodawca w projekcie uchwały uzasadnił niniejszą zmianę tym, że FIZ były wykorzystywane do prowadzenia działalności holdingowej zamiast inwestycyjnej, a co za tym idzie - do unikania opodatkowania z wykorzystaniem m.in. transparentnych podatkowo spółek SCSp.

${ }^{12}$ Pozostała część zysku jest podzielona następująco: 0,1\% udziału w zysku polskiej spółki komandytowej ma polska spółka z o.o. (komplementariusz), a 0,1\% udziału w zyskach spółki SCSp posiada luksemburska spółka kapitałowa S.A.R.L. (komplementariusz). 
Zmiana przepisów podatkowych sprawiła, że przedsiębiorstwa wykorzystujące strukturę z udziałem spółki SCSp musiały dostosować swoją strategię podatkową do nowelizacji ustawy o CIT. Proces dostosowawczy polegał na restrukturyzacji, w ramach której FIZ sprzedał posiadane akcje bądź udziały spółki luksemburskiej wraz z jej zależnymi spółkami komandytowymi polskiej spółce kapitałowej lub komandytowo-akcyjnej (spółka celowa) mającej status podatnika. Aby sfinansować nabycie akcji, spółka celowa wyemitowała obligacje. Umożliwiło to wymianę bezgotówkową, w wyniku której fundusz wszedł w posiadanie obligacji spółek celowych, a spółki celowe pozyskały akcje spółki SCSp, które wchodziły w skład portfela inwestycyjnego funduszu. Dzięki tej transakcji nabywca akcji stał się udziałowcem spółki SCSp, a także, za jej pośrednictwem, spółki komandytowej generującej dochody z prowadzonej działalności gospodarczej. W wyniku emisji obligacji spółka celowa zaciągnęła jednocześnie zobowiązanie finansowe wobec FIZ, w związku z czym będzie zobowiązana do spłacania odsetek od obligacji, które stanowić będą koszt uzyskania przychodu.

Schemat 3. Struktura z wykorzystaniem spółki prawa luksemburskiego po restrukturyzacji

Dochód z udziału w spółkach
zależnych pomniejszony
o koszt odsetek od obligacji
- efektywny brak podatku

Podmiot transparentny podatkowo - brak podatku

Podmiot transparentny podatkowo - brak podatku

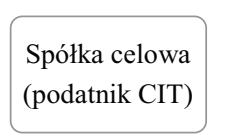

emisja obligacji

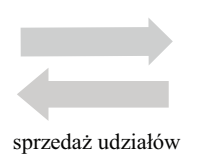

Fundusz Inwestycyjny Zamknięty
Zwolnienie

z opodatkowania dochodów z odsetek i zbycia udziałów - brak podatku
SCSp spółka luksemburska

Źródło: opracowanie własne na podstawie ostrzeżenia Ministerstwa Finansów przed optymalizacją podatkową FIZ z wykorzystaniem obligacji z dnia 8 maja 2017 r.

Po restrukturyzacji przychody generowane w wyniku działalności gospodarczej spółki komandytowej zostaną opodatkowane dopiero na poziomie spółki celowej, gdzie zostaną pomniejszone o koszty odsetek od wyemitowanych obligacji. Koszt odsetek od obligacji może w całości lub w dominującej części konsumować dochody z udziału w spółkach zależnych, obniżając tym samym podstawę opodatkowania i wysokość należnego podatku. Restrukturyzacja z wykorzystaniem obligacji pozwoliła powrócić do stanu sprzed nowelizacji ustawy o CIT, 
gdyż dochód z działalności gospodarczej trafi do funduszu, nie zostając przy tym na żadnym etapie pomniejszony o podatek.

Restrukturyzacja ta, związana ze zniesieniem od stycznia 2017 r. zwolnienia podmiotowego FIZ w podatku dochodowym, została jednak zauważona przez Ministerstwo Finansów, które 8 maja 2017 r. wydało ostrzeżenie przed optymalizacją podatkową FIZ z wykorzystaniem obligacji. W ostrzeżeniu wskazano, że omówiony proces mógł mieć na celu przede wszystkim osiągnięcie korzyści podatkowej, sprzecznej z przedmiotem i celem przepisu ustawy podatkowej, a sposób działania uczestniczących w niej podmiotów był sztuczny.

Zdaniem autora nie przesądza to jednak o zastosowaniu klauzuli przeciw unikaniu opodatkowania ${ }^{13}$ wobec podmiotów wchodzących w skład struktury. Należy zwrócić uwagę na formalnoprawne skutki opublikowania na stronie internetowej Ministerstwa Finansów ostrzeżenia przed optymalizacją podatkową FIZ z wykorzystaniem obligacji. Zgodnie z art. 14a § 1 Ordynacji podatkowej minister właściwy do spraw finansów publicznych dąży do zapewnienia jednolitego stosowania przepisów prawa podatkowego przez organy podatkowe w dwojaki sposób:

- dokonując ich interpretacji z urzędu lub na wniosek (interpretacje ogólne),

- wydając z urzędu ogólne wyjaśnienia przepisów prawa podatkowego dotyczące stosowania tych przepisów.

Stanowisko władz podatkowych dotyczące zastosowania klauzuli przeciwko unikaniu opodatkowania reguluje m.in. art. $119 \mathrm{y} \S 1$ i $\S 2$ ordynacji podatkowej, zgodnie z którym szef krajowej administracji skarbowej wydaje opinię zabezpieczającą lub odmawia jej wydania w zależności od tego, czy okoliczności wskazują, że do przedsięwziętych czynności ma zastosowanie art. 119a ordynacji podatkowej. Ostrzeżenie ministra finansów przed optymalizacją podatkową FIZ z wykorzystaniem obligacji zostało opublikowane bez żadnej podstawy prawnej, zatem jego formalna moc jest taka sama, jak moc wypowiedzi prasowej pracowników Ministerstwa Finansów - przede wszystkim nie ma mocy interpretacji ogólnej wydawanej na podstawie art. 14a ordynacji podatkowej ani nie jest odmową wydania opinii zabezpieczającej. Należy mieć na uwadze to, że wydawanie ostrzeżeń jest inicjatywą własną dyrektorów departamentów Ministerstwa Finansów mającą na celu komunikację z podatnikami, która w założeniu ma działać przede wszystkim prewencyjnie (Najwyższa Izba Kontroli 2018). Co do zasady samo opublikowanie ostrzeżenia nie niesie ze sobą skutków podatkowych dla uczestniczących w strukturach podmiotów.

W kontekście ryzyka zastosowania art. 119a ordynacji podatkowej do omówionej struktury międzynarodowego planowania podatkowego należy zaznaczyć, że aby mógł on zostać zastosowany, muszą zostać spełnione łącznie trzy przesłanki:

${ }^{13}$ Zob. art. 119a-119f Ustawy z dnia 29 sierpnia 1997 r. - Ordynacja podatkowa 
- celem czynności było przede wszystkim osiągnięcie korzyści podatkowej,

- korzyść podatkowa jest sprzeczna z przedmiotem i celem przepisu ustawy podatkowej,

- sposób działania był sztuczny.

Należy zatem ocenić, czy istnieją podstawy, aby przyjąć, że osiągniecie korzyści podatkowej było jedynym celem czynności. W ocenie autora korzyści z zastosowanej w 2017 r. nowej strategii podatkowej nie kończą się wyłącznie na aspekcie stricte podatkowym. Sama wartość księgowa i rynkowa posiadanych przez FIZ instrumentów przed rokiem 2017 i po nim jest porównywalna, jednak inaczej kształtują się zyski z tytułu ich posiadania. Przed 2017 r. FIZ mógł nie otrzymywać zysków z luksemburskiej spółki SCSp, gdyż sama spółka mogła nie osiągać zysków z zależnych spółek osobowych, ponieważ czerpanie zysków $z$ tytułu dywidend od spółek zależnych jest zawsze warunkowe i niepewne.

Zupełnie inaczej, jeśli chodzi o bieżące korzyści, tj. wpływy, przedstawia się sytuacja majątkowa FIZ po 2017 r. W wyniku zamienienia akcji na obligacje FIZ zagwarantował sobie stałe źródło zysków w postaci odsetek od obligacji. Przyjmując średnie oprocentowanie obligacji na poziomie 5\% w przypadku posiadania obligacji na 100 milionów zł, FIZ osiągnąłby dodatkowy zysk z aktywów wynoszący 5 milionów zł. Posiadanie akcji SCSp o takiej samej wartości nie zapewniało tak wysokich stałych zysków.

Odsetki od obligacji są zwolnione z podatku CIT, zatem korzyść podatkowa wynosi $19 \%$ od 100 jednostek. Wskazuje to jednoznacznie, że korzyść podatkowa nie jest jedyną korzyścią zastosowania nowej struktury. W dodatku otrzymywane przez FIZ odsetki od obligacji mogą być reinwestowane w różne instrumenty finansowe, co jest kolejnym dodatkowym źródłem zysków funduszu.

Należy również zwrócić uwagę na to, że gdyby nie doszło do restrukturyzacji, FIZ, nie mając żadnego wpływu na wypłaty zysków do i ze spółki SCSp, byłby zobowiązany do płacenia podatku dochodowego od spółek osobowych przypisywanego mu jedynie statystycznie na podstawie art. 8 ustawy o CIT, a to mogłoby prowadzić do trudności z utrzymaniem płynności funduszu i negatywnie przełożyć się na wartość jego aktywów.

W odniesieniu do sprzeczności z przedmiotem i celem przepisu ustawy podatkowej, zdaniem autora, dążenie przez fundusz inwestycyjny zamknięty aktywów niepublicznych (FIZAN) do osiągania dochodów zwolnionych z podatku o charakterze kapitałowym i pasywnym, a takim są odsetki od obligacji, nie może zostać uznane za działanie sprzeczne z przedmiotem i celem ustawy podatkowej.

Jeśli chodzi o trzecią przesłankę, dotyczącą oceny sztuczności działania, to definiuje ją art. 119c §1 ordynacji podatkowej, zgodnie z którym sposób działania uznaje się za sztuczny, jeżeli na podstawie istniejących okoliczności należy przyjąć, że nie zostałby on zastosowany przez podmiot działający rozsądnie i kierujący się zgodnymi z prawem celami innymi niż osiągnięcie korzyści 
podatkowej. W analizowanym przypadku papiery wartościowe (akcje spółki SCSp) zostały sprzedane istniejącej bądź nowo powołanej spółce kapitałowej lub komandytowej, która jednocześnie emitowała obligacje, a od ceny sprzedanych akcji została potrącona cena nabywanych obligacji. Zdaniem autora jedyną alternatywną czynnością odpowiadającą tej, która została opisana powyżej, mógłby być aport akcji SCSp do spółki będącej emitentem obligacji. Jeśli bowiem uznać sprzedaż akcji z rozliczeniem ceny przez potrącenie ceny obligacji za czynność sztuczną, to odpowiednią czynnością musiałby być aport. Nie mogłaby to być np. darowizna, gdyż FIZAN uzyskał w zamian inny instrument finansowy, zatem czynność tak czy inaczej była odpłatna i ekwiwalentna. Skoro w wyniku dorozumianego aportu obecny emitent jest właścicielem SCSp, to wyłącznie on może być podatnikiem CIT dochodów osiąganych przez spółki kapitałowe zależne od SCSp. Już zatem z tego powodu nieuprawnione jest zastosowanie w analizowanej strukturze przepisów omawianej klauzuli, zgodnie z którą FIZAN zostałby uznany za podatnika CIT dochodów spółek komandytowych. Ponadto do dnia 30 kwietnia 2020 r. - zatem po prawie czterech latach od wejścia w życie przepisów klauzuli przeciwko unikaniu opodatkowania - nie została wydana ani jedna decyzja wymiarowa w związku z międzynarodowym planowaniem podatkowym $\mathrm{z}$ wykorzystaniem obligacji nabywanych $\mathrm{w}$ ramach grupy podmiotów powiązanych, w których uczestniczą fundusze inwestycyjne zamknięte ${ }^{14}$.

\section{Zakończenie}

Podatki mają istotny wpływ na funkcjonowanie przedsiębiorstwa, zwłaszcza podatki dochodowe, które bezpośrednio oddziałują na płynność przedsiębiorstwa i zmniejszają jego majątek. Przedsiębiorcy podejmują zatem różne działania mające na celu zmniejszenie wysokości obciążeń podatkowych. Jednym z ich jest zastosowanie planowania podatkowego i wdrożenie odpowiedniej strategii podatkowej. Na strategię podatkową składają się czynności, dzięki którym przedsiębiorstwo będzie mogło zminimalizować wydatki podatkowe, ograniczając jednocześnie ryzyko podatkowe, co finalnie powinno prowadzić do poprawy konkurencyjności i efektywności przedsiębiorstwa na rynku.

W niniejszym opracowaniu przeanalizowano pojęcie unikania opodatkowania oraz istotę międzynarodowego planowania podatkowego, a następnie szczegółowo omówiono jeden ze schematów planowania podatkowego w praktyce. Analiza schematu uwidoczniła możliwości, jakie niesie za sobą międzynarodowe planowanie podatkowe. W świetle obowiązujących w Polsce oraz w Wielkim

\footnotetext{
${ }^{14}$ Informacja uzyskana 30 kwietnia 2020 r. w trybie art. 2 ust. 1 i art. 10 ust. 1 ustawy z dnia 6 września 2001 r. o dostępie do informacji publicznej (Dz.U. z 2016 r., poz. 1764 z późn. zm.)
} 
Księstwie Luksemburga przepisów podatkowych możliwe jest zarówno odroczenie momentu zapłaty podatku dochodowego od osób prawnych, jak i obniżenie jego wysokości niemalże do zera. Taką możliwość daje zastosowanie struktury wykorzystującej FIZ oraz luksemburskie spółki SCSp.

$\mathrm{W}$ opracowaniu wzięto również pod uwagę zmieniające się przepisy ustawy o podatku dochodowym od osób prawnych, które miały być odpowiedzią polskiego prawodawcy na stosowanie przez podatników tego rodzaju struktur. Zmiany te nie miały jednak znaczącego wpływu na zaprezentowany schemat - został on zrestrukturyzowany i dostosowany do nowych wymogów prawnych, tak aby funkcjonował on zgodnie z przepisami prawa, pozwalając jednocześnie na zachowanie płynących z jego stosowania korzyści podatkowych.

Z przeprowadzonej analizy przepisów klauzuli przeciwko unikaniu opodatkowania wynika, że nie znajduje ona zastosowania w przypadku międzynarodowego planowania podatkowego z wykorzystaniem spółki prawa luksemburskiego i FIZ. Świadczy o tym brak chociażby jednej decyzji wymiarowej organów skarbowych po prawie czterech latach od momentu wejścia w życie analizowanej klauzuli.

\section{Bibliografia}

Famulska T. (1998), Oddziaływanie systemu podatkowego na rynek finansowy. Katowice: Akademia Ekonomiczna.

Famulska T. (2015), Reakcje przedsiębiorstwa na obciązenia podatkowe (na przykładzie podatku od towarów i ustug), „Studia Ekonomiczne”, nr 1 (73).

Głuchowski J. (2002), Polskie prawo podatkowe. Warszawa: Lexis Nexis.

Gomułowicz A. (2013), Podatki a etyka. Warszawa: Wolters Kluwer Polska SA.

Griffin R.W. (2013), Podstawy zarządzania organizacjami. Warszawa: Wydawnictwo Naukowe PWN.

Gwiazdowski R. (2019), O Reakcjach podatników na opodatkowanie i o przerzucalności podatków. Warszawa: Ius Novum.

Ignaciuk E. (2014), Skuteczność optymalizacyjna polityki rynku pracy realizowanej przez kraje skandynawskie. Gdańsk: Polskie Towarzystwo Ekonomiczne Oddział w Gdańsku.

Kudert S., Jamroży M. (2007), Optymalizacja opodatkowania dochodów przedsiębiorców. Warszawa: Wolters Kluwer.

Kuzińska H. (2018), Ucieczka przed podatkami i kontrola podatkowa. Warszawa: Poltext.

Kuźnicki B. (2017), Optymalizacja podatkowa w podatkach dochodowych. Warszawa. 
Ladziński A. (2008), Prawne granice optymalizacji podatkowej, „Przegląd Podatkowy", nr 6.

Lipowski T. (2004), Raje podatkowe a unikanie opodatkowania. Warszawa: C.H. Beck.

Najwyższa Izba Kontroli (2018), Wystapienie pokontrolne KBF.410.004.01.2018, www.gov.pl/attachment/9907b571-7fb6-481a-8dd8-69b55e5885e1 (data dostępu: 3.08.2020).

Ofiarski Z. (2013), Ogólne prawo podatkowe. Zagadnienia materialno-prawne i proceduralne. Warszawa: Lexis Nexis.

Pach J. (2016), Podatkowe uwarunkowania przedsiębiorczości w teorii i praktyce gospodarczej, „Prace Komisji Geografii Przemysłu Polskiego Towarzystwa Geograficznego", nr 1 (30).

Pietrewicz M. (1998), Polityka fiskalna. Warszawa: Poltext.

Poszwa M. (2007), Zarzadzanie podatkiem w matej i średniej firmie. Warszawa: C.H. Beck.

Spoz A. (2012), Wybrane metody optymalizacji podatkowej przedsiębiorstw, „Finanse, Rynki Finansowe, Ubezpieczenia", nr 52.

Spoz A. (2012), Wybrane metody optymalizacji podatkowej przedsiębiorstw, „Zeszyty Naukowe Uniwersytetu Szczecińskiego", nr 708.

Ustawa z dnia 26 lipca 1991 r. o podatku dochodowym od osób fizycznych (Dz.U. z 1991 r., nr 80, poz. 350; tekst jednolity Dz.U. z 2015 r.).

Ustawa z dnia 15 lutego 1992 r. o podatku dochodowym od osób prawnych (tekst jednolity Dz.U. z 2014 r., poz. 851).

Ustawa z dnia 15 września 2000 r. - Kodeks spółek handlowych (Dz.U. z 2000 r., nr 94, poz. 1037; tekst jednolity Dz.U. z 2019 r.).

Walicka M. (2012), Optymalizacja podatkowa w działalności gospodarczej matych przedsiębiorstw, „Finanse, Rynki Finansowe, Ubezpieczenia”, nr 52.

Walicka M. (2012), Optymalizacja podatkowa w działalności gospodarczej matych przedsiębiorstw, „Zeszyty Naukowe Uniwersytetu Szczecińskiego” nr 708 .

Wolański R. (2009), System podatkowy w Polsce. Warszawa: Wolters Kluwer.

Wyciślok J. (2013), Optymalizacja podatkowa, legalne zmniejszenie obciążé podatkowych. Warszawa: C.H. Beck.

Związek Przedsiębiorców i Pracodawców (2019), Absurdalny system opodatkowania firm w Polsce hamuje rozwój przedsiębiorczośc. Warszawa. 


\section{Streszczenie}

System podatkowy w Polsce cechuje się dużą liczbą obciążeń podatkowych oraz skomplikowaną konstrukcją poszczególnych podatków. Wpływa to bezpośrednio na decyzje podmiotów gospodarczych, które przyjmują różne postawy w odpowiedzi na wysokie opodatkowanie ich dochodów. Celem artykułu jest przedstawienie jednego ze sposobów legalnego międzynarodowego planowania podatkowego umożliwiającego minimalizację opodatkowania dochodów przedsiębiorców dzięki wykorzystaniu odpowiednich regulacji prawnych oraz form organizacyjno-prawnych prowadzonej działalności gospodarczej. W artykule zwrócono również uwagę na proces dostosowywania struktur do zmieniających się przepisów podatkowych.

Słowa kluczowe: podatki, planowanie podatkowe, unikanie opodatkowania, optymalizacja podatkowa

\section{Summary}

International tax planning involving a company incorporated under luxembourg law

Poland's tax system has a large number of tax burdens and a complicated structure of individual taxes. This directly affects the decisions made by business entities, which take different attitudes in response to high taxation of their income. One of the reactions of enterprises to taxation may be the use of tax planning. The aim of the article is to present one of the ways of legal international tax planning, which enables minimizing the taxation of entrepreneurs' income through the use of appropriate structures of legal regulations and legal forms of conducted business activity. The article also draws attention to the process of adapting the created constructions to the changing tax regulations.

Keywords: taxation, tax planning, tax avoidance, tax optimization

JEL: H24, H26, H32 